\title{
Differences in the Accumulation and Distribution Profile of Heavy Metals and Metalloid between Male and Female Crayfish (Astacus leptodactylus)
}

\author{
Evren Tunca $\cdot$ Esra Ucuncu $\cdot$ Alper Devrim Ozkan • \\ Zeynep Ergul Ulger • Ahmet Ertuğrul Cansızoğlu • \\ Turgay Tekinay
}

Received: 28 May 2012/ Accepted: 29 January 2013/Published online: 17 February 2013

(C) Springer Science+Business Media New York 2013

\begin{abstract}
Concentrations of selected heavy metals and a metalloid were measured by ICP-MS in crayfish (Astacus leptodactylus) collected from Lake Hirfanli, Turkey. Aluminum (Al), chromium $\left({ }^{52} \mathrm{Cr},{ }^{53} \mathrm{Cr}\right)$, copper $\left({ }^{63} \mathrm{Cu},{ }^{65} \mathrm{Cu}\right)$, manganese $(\mathrm{Mn})$, nickel (Ni) and arsenic (As) were measured in the exoskeleton, gills, hepatopancreas and abdominal muscle tissues of 60 crayfish of both genders. With the exception of $\mathrm{Al}$, differences were determined between male and female cohorts for the accumulation trends of the abovementioned elements in the four tissues. It was also noted that the accumulation rates of $\mathrm{Ni}$ and As were significantly lower in gill tissue of females compared to males and no significant difference was observed for $\mathrm{Cu}$ isotopes in female crayfish. Cluster Analysis (CA) recovered similar results for both genders, with links between accumulations of $\mathrm{Ni}$ and As being notable. Accumulation models were described separately for male and female crayfish using regression analysis, and are presented for models where $\mathrm{R}^{2}>0.85$.
\end{abstract}

Keywords Bioaccumulation - Bioindicator - Cluster analysis (CA) · Regression Analysis

E. Tunca $\cdot$ A. D. Ozkan $\cdot$ T. Tekinay $(\bowtie)$

UNAM-Institute of Materials Science and Nanotechnology,

Bilkent University, 06800 Bilkent, Ankara, Turkey

e-mail: ttekinay@bilkent.edu.tr

E. Ucuncu $\cdot$ Z. E. Ulger

Department of Biology, Faculty of Science, Ankara University, 06100 Ankara, Turkey

A. E. Cansızoğlu

Boston Children's Hospital and Harvard Medical School,

F. M. Kirby Center for Neurobiology, Boston, MA, USA
Due to the toxic effects many heavy metals display even at very low concentrations, heavy metal pollution poses a serious threat to human health and the environment (Suárez-Serrano et al. 2010; Agrawal et al. 2011). Consequently, it is important to gain an understanding of the presence and distribution of heavy metals in the environment, especially in aquatic ecosystems where heavy metal pollution can be particularly dangerous. Bioindicator organisms are well-suited for monitoring heavy metal pollution and its impact on the environment. Prior studies indicate that crayfish can accumulate heavy metals with rates depending on the external concentration of the metal (Guner 2007; Soedarini et al. 2012). Due to this potential, crayfish have been used as bioindicator species in many studies (Lopez et al. 2004; Hothem et al. 2007; Hagen and Sneddon 2009). Through their position in the food web, crayfish also have the potential for transferring toxins and contaminants to other organisms of higher trophic levels (Wigginton and Birge 2007).

To improve our capacity to accurately detect and monitor heavy metal pollution, it is important to understand all factors that influence the accumulation of metals in crayfish. Many studies have determined the accumulation of metals in crayfish tissues in a dose and/or time dependent manner, without taking into account significant differences in tissue concentration levels of heavy metals or the possibility of selective accumulation of a specific heavy metal in males or females (Kouba et al. 2010). Gender is one of the most important factors bearing a potential effect on heavy metal accumulation. The aim of this study was to understand the differences in heavy metals and metalloid accumulation by crayfish (Astacus leptodactylus) tissues, with special focus on the distribution trends between male and female crayfish. We also sought to examine the interrelationships between metals, and to model the accumulation for male and female crayfish separately. 


\section{Materials and Methods}

Sixty crayfish specimens (A. leptodactylus), 37 males and 23 females, of varying sizes were collected from Lake Hirfanll, a dam lake located in Kırşehir, Turkey ( $39^{\circ} 16^{\prime}$ $20.28^{\prime \prime} \mathrm{N}, 33^{\circ} 31^{\prime} 7.68^{\prime \prime} \mathrm{E}$ ) and transported in Igloo cooler boxes. Crayfish specimens were stored at $-20^{\circ} \mathrm{C}$ in plastic bags until cephalothorax, exoskeleton, gills, hepatopancreas and abdominal muscles were dissected. Samples of those tissues were then prepared for ICP-MS measurements by digestion, following the method of Bernhard (1976). An X-Series II ICP-MS (Thermo Fisher Scientific Advanced Mass Spectrometry, Bremen, Germany), equipped with ID100 Autodiluter and Cetac Asx-260 autosampler accessories, was utilized. Dilutions were made with a $2 \%$ nitric acid matrix in ultrapure water. All standard curves were prepared by using the QCS-27 series of elements (High Purity Standards, South Carolina, USA). Concentrations of the relevant element in the tissue samples were taken into account and a correlation coefficient over 0.99 was obtained for each calibration curve. Measurements of standards were conducted after every 20 samples to ensure consistency, and $10 \mathrm{ppb}{ }^{209} \mathrm{Bi}$ was utilized as an internal standard. Interferences created by IA and IIA metals were removed via Collision Cell Technology (CCT) (Pick et al. 2010). Three runs were conducted for each sample. The dwell time was $10 \mathrm{~ms}$ for all elements except $\mathrm{Al}$, for which a dwell time of $50 \mathrm{~ms}$ was used due to this element's low atomic weight. Sampling and washing times were $90 \mathrm{~s}$ each. ${ }^{27} \mathrm{Al},{ }^{52} \mathrm{Cr},{ }^{53} \mathrm{Cr},{ }^{55} \mathrm{Mn},{ }^{60} \mathrm{Ni},{ }^{63} \mathrm{Cu},{ }^{65} \mathrm{Cu}$ and ${ }^{75} \mathrm{As}$ were the heavy metals measured. LUTS-1 non-defatted lobster hepatopancreas (National Research Council Canada, Ontario, Canada) was utilized as reference material; sample measurements were adjusted using the recovery rates obtained. Limits of detection were $0.037 \pm 0.019$, $0.094 \pm 0.009, \quad 0.031 \pm 0.001, \quad 0.048 \pm 0.002, \quad 0.051 \pm$ 0.025 , and $0.005 \pm 0.025 \mathrm{ppb}$ for $\mathrm{Al}, \mathrm{Cr}, \mathrm{Mn}, \mathrm{Ni}, \mathrm{Cu}$ and As; respectively. No sample was found to have any metal concentration below detection limits. Recovery rates were $99.0 \%, 95.36 \%, 96.14 \%, 115.6 \%, 155.02 \%$ and $15.85 \%$ for $\mathrm{Al}, \mathrm{Cr}, \mathrm{Mn}, \mathrm{Ni}, \mathrm{Cu}$ and As; respectively. High $\mathrm{Cu}$ recovery rates are probably caused by interference by ${ }^{25} \mathrm{Mg}$ and ${ }^{40} \mathrm{Ar}$. Very low As recovery rates are attributable to the low temperature of sublimation for this element $\left(613{ }^{\circ} \mathrm{C}\right)$, as the extraction method utilized substantially higher temperatures.

SPSS 17 (IBM, Portsmouth, UK) was used for all statistical analysis. Prior to one-way ANOVA and independent $t$ test analysis, all results were subjected to the Kolmogorov-Smirnov Test to observe the normality of data distribution. A logarithmic transformation was applied for non-parametric data and all results were subjected to a second Kolmogorov-Smirnov Test to pinpoint non-parametric data after transformation. For determining the homogeneity of variance, Levene's test was carried out. Tukey's test was utilized for data with homogeneous variance, and Tamhane's test was applied for data with heterogeneous variance. For non-parametric data, a Mann-Whitney U Test was carried out following a Kruskal-Wallis Test (Barrento et al. 2008). In this study, hierarchical clustering methods based on a Euclidean distance measure and Ward's hierarchical agglomerative clustering technique were used (Lopez et al. 2004). The data were standardized following a z-score method. Multiple linear regression analysis was used to predict the concentrations of heavy metals in each of the four tissues tested. The analysis was applied to all heavy metals in all tissues; however, only models displaying $\mathrm{R}^{2}>0.85$ were considered in this paper. Normality graphs were inspected to observe the parameter distribution. A stepwise method was chosen during analysis.

\section{Results and Discussion}

The highest concentrations of elements were generally obtained in gill tissue for both genders (Tables 1a, b, 2a, b; Fig. 1a, b), likely because of the direct contact of the gills with the outside environment (Kurun et al. 2010). The active role that gills play in the regulation of ionic balance might be another reason (Alcorlo et al. 2006). For Al, in both male and female specimens, accumulation differences between every tissue were statistically significant, except the difference between the exoskeleton and abdominal muscle. In males, the order of accumulation of $\mathrm{Al}$ was gills $>$ exoskeleton $\approx$ abdominal muscle $>$ hepatopancreas. In females, the order of $\mathrm{Al}$ accumulation was gills $>$ exoskeleton $=$ abdominal muscle $>$ hepatopancreas. Gills were previously reported to play an important role in $\mathrm{Al}$ intake, and accumulation of this metal was also observed in hepatopancreas and muscles to a lesser degree (Alexopoulos et al. 2003; Kurun et al. 2010). While those observations are supported in this study, we have also observed a relatively high $\mathrm{Al}$ accumulation in the exoskeleton, comparable to the muscle accumulation rates. The high exoskeletal concentration of $\mathrm{Al}$ observed may be explained by the fact that the specimens were collected in autumn. Due to the relatively lower ambient temperatures, the metabolic rates of crayfish are slower and moulting is expected to be less frequent. As such, greater amounts of $\mathrm{Al}$ may have accumulated on the exoskeleton between moults. Al is also a common sediment constituent and its widespread presence may further account for the high exoskeletal Al content. Increased exposure times to heavy metals have previously been reported to cause higher accumulation rates in the exoskeleton (Guner 2007).

$\mathrm{Cr}$ is an important trace element for many organisms, but has toxic and mutagenic effects in higher concentrations (Srinath et al. 2002). $\mathrm{Cr}^{+6}$ in particular is very toxic, and 
Table 1 Means of comparison for males

\begin{tabular}{|c|c|c|c|c|}
\hline & Tissue (I) & Tissue (J) & Mean dif. (I-J) & Sig. \\
\hline \multicolumn{5}{|c|}{ (a) (ANOVA) } \\
\hline \multirow[t]{6}{*}{$\mathrm{Al}$} & Exo. & Gills & $-1.53284^{*}$ & .000 \\
\hline & & Hepa. & $1.06363^{*}$ & .000 \\
\hline & & Muscle & .13223 & .997 \\
\hline & Gills & Hepa. & $2.59646^{*}$ & .000 \\
\hline & & Muscle & $1.66507^{*}$ & .000 \\
\hline & Hepa. & Muscle & $-.93139^{*}$ & .029 \\
\hline \multirow[t]{6}{*}{$\mathrm{Mn}$} & Exo. & Gills & $.73293^{*}$ & .000 \\
\hline & & Hepa. & -.48586 & .082 \\
\hline & & Muscle & $.91283^{*}$ & .025 \\
\hline & Gills & Hepa. & $-1.21879^{*}$ & .000 \\
\hline & & Muscle & .17990 & .992 \\
\hline & Hepa. & Muscle & $1.39869^{*}$ & .000 \\
\hline \multirow[t]{6}{*}{${ }^{63} \mathrm{Cu}$} & Exo. & Gills & .16431 & .968 \\
\hline & & Hepa. & $.85414 *$ & .000 \\
\hline & & Muscle & .33468 & .205 \\
\hline & Gills & Hepa. & $.68983^{*}$ & .012 \\
\hline & & Muscle & .17037 & .932 \\
\hline & Hepa. & Muscle & $-.51946^{*}$ & .021 \\
\hline \multirow[t]{7}{*}{${ }^{65} \mathrm{Cu}$} & Exo. & Gills & -.24850 & .713 \\
\hline & & Hepa. & $.73615^{*}$ & .000 \\
\hline & & Muscle & .33229 & .152 \\
\hline & Gills & Hepa. & $.98465^{*}$ & .000 \\
\hline & & Muscle & $.58079 *$ & .022 \\
\hline & Hepa. & Muscle & -.40386 & .150 \\
\hline & Tissue & Mean rank & Sum of Rank & Sig. \\
\hline \multicolumn{5}{|c|}{ (b) (Mann-Whitney U) } \\
\hline \multirow[t]{12}{*}{${ }^{52} \mathrm{Cr}$} & Exo. & 20.92 & 774 & .000 \\
\hline & Gills & 54.08 & 2001 & \\
\hline & Exo. & 42.61 & 1576.5 & .041 \\
\hline & Hepa & 32.39 & 1198.5 & \\
\hline & Exo. & 48.43 & 1792 & .000 \\
\hline & Muscle & 26.57 & 983 & \\
\hline & Gills & 55.65 & 2059 & .000 \\
\hline & Hepa. & 19.35 & 716 & \\
\hline & Gills & 56.00 & 2072 & .000 \\
\hline & Muscle & 19.00 & 703 & \\
\hline & Hepa. & 43.08 & 1594 & .026 \\
\hline & Muscle & 31.92 & 1181 & \\
\hline \multirow[t]{12}{*}{${ }^{53} \mathrm{Cr}$} & Exo. & 19.00 & 703 & .000 \\
\hline & Gills & 56.00 & 2072 & \\
\hline & Exo. & 23.57 & 872 & .000 \\
\hline & Hepa & 51.43 & 1903 & \\
\hline & Exo. & 28.22 & 1044 & .000 \\
\hline & Muscle & 46.78 & 1731 & \\
\hline & Gills & 55.43 & 2051 & .000 \\
\hline & Hepa. & 19.57 & 724 & \\
\hline & Gills & 56.00 & 2072 & .000 \\
\hline & Muscle & 19.00 & 703 & \\
\hline & Hepa. & 47.32 & 1751 & .000 \\
\hline & Muscle & 27.68 & 1024 & \\
\hline
\end{tabular}

Table 1 continued

\begin{tabular}{|c|c|c|c|c|}
\hline & Tissue & Mean rank & Sum of Rank & Sig. \\
\hline \multirow[t]{12}{*}{$\mathrm{Ni}$} & Exo. & 23.35 & 864 & .000 \\
\hline & Gills. & 51.65 & 1911 & \\
\hline & Exo. & 33.51 & 1240 & .111 \\
\hline & Hepa. & 41.49 & 1535 & \\
\hline & Exo & 55.19 & 2042 & .000 \\
\hline & Muscle & 19.81 & 733 & \\
\hline & Gills & 48.35 & 1789 & .000 \\
\hline & Hepa. & 26.65 & 986 & \\
\hline & Gills & 56.00 & 2072 & .000 \\
\hline & Muscle & 19.00 & 703 & \\
\hline & Hepa. & 53.64 & 1984.50 & .000 \\
\hline & Muscle & 21.36 & 790.50 & \\
\hline \multirow[t]{12}{*}{ As } & Exo. & 31.58 & 1168.50 & .018 \\
\hline & Gills & 43.42 & 1606.50 & \\
\hline & Exo. & 36.00 & 1332.00 & .549 \\
\hline & Hepa. & 39.00 & 1443.00 & \\
\hline & Exo & 56.00 & 2072.00 & .000 \\
\hline & Muscle & 19.00 & 703.00 & \\
\hline & Gills & 40.08 & 1483.00 & .302 \\
\hline & Нера. & 34.92 & 1292.00 & \\
\hline & Gills & 56.00 & 2072.00 & .000 \\
\hline & Muscle & 19.00 & 703.00 & \\
\hline & Hepa. & 55.95 & 2070.00 & .000 \\
\hline & Muscle & 19.05 & 705.00 & \\
\hline
\end{tabular}

* The mean difference is significant at the 0.05 level $(p<0.05)$

Hepa.: Hepatopancreas, Exo.: Exoskeleton, Muscle: Abdominal muscle

generally not utilized in biological systems (Vinod et al. 2010). In male specimens, ${ }^{52} \mathrm{Cr}$ accumulations were significantly different for each tissue. While similar trends in accumulation were observed in females, no significant difference was present between the hepatopancreas and muscle accumulation rates. In both sexes, gills and the exoskeleton were the prime sites of chromium accumulation, a result previously reported in laboratory studies (Bollinger et al. 1997). In males, the order of accumulation of $\mathrm{Cr}$ was gills $>$ exoskeleton $>$ hepatopancreas $>$ abdominal muscle. In females, the order was gills $>$ exoskeleton $>$ hepatopancreas $\approx$ abdominal muscle. Statistically significant differences were observed between the ${ }^{53} \mathrm{Cr}$ accumulations of each tissue of male specimens, while the female cohort was similar except for the lack of a significant difference between the accumulation rates of the exoskeleton and abdominal muscles. It is curious that the hepatopancreas accumulation was greater than exoskeletal accumulation for ${ }^{53} \mathrm{Cr}$, while the opposite was true for ${ }^{52} \mathrm{Cr}$. This trend might be caused by fractionation during absorption of chromium, especially if the exoskeleton can selectively absorb ${ }^{52} \mathrm{Cr}$ over ${ }^{53} \mathrm{Cr}$. In males, the order of ${ }^{53} \mathrm{Cr}$ accumulation was gills $>$ hepatopancreas $>$ exoskeleton $>$ abdominal muscle. In females, 
Table 2 Means of comparison for females

\begin{tabular}{|c|c|c|c|c|}
\hline & Tissue (I) & Tissue(J) & Mean dif. (I-J) & Sig. \\
\hline \multicolumn{5}{|c|}{ (a) (ANOVA) } \\
\hline \multirow[t]{6}{*}{$\mathrm{Al}$} & \multirow[t]{3}{*}{ Exo. } & Gills & $-1.67459^{*}$ & .000 \\
\hline & & Нера. & $.72980 *$ & .044 \\
\hline & & Muscle & -.25912 & .955 \\
\hline & \multirow[t]{2}{*}{ Gills } & Нера. & $2.40439 *$ & .000 \\
\hline & & Muscle & $1.41546 *$ & .000 \\
\hline & Hера. & Muscle & $-.98893 *$ & .040 \\
\hline \multirow[t]{6}{*}{ Mn } & \multirow[t]{3}{*}{ Exo. } & Gills & $1.12352 *$ & .000 \\
\hline & & Hepa. & -.45420 & .557 \\
\hline & & Muscle & .65574 & .505 \\
\hline & \multirow[t]{2}{*}{ Gills } & Нера. & $-1.57772 *$ & .000 \\
\hline & & Muscle & -.46778 & .757 \\
\hline & Нера. & Muscle & 1.10993 & .061 \\
\hline \multirow[t]{6}{*}{$\mathrm{Ni}$} & \multirow[t]{3}{*}{ Exo } & Gills & -.38475 & .261 \\
\hline & & Нера & -.30435 & .095 \\
\hline & & Muscle & $1.27252 *$ & .000 \\
\hline & \multirow[t]{2}{*}{ Gills } & Нера & .05243 & 1.000 \\
\hline & & Muscle & .08039 & .000 \\
\hline & Нера & Muscle & $1.57688 *$ & .000 \\
\hline \multirow[t]{6}{*}{${ }^{63} \mathrm{Cu}$} & \multirow[t]{3}{*}{ Exo } & Gills & .39532 & .572 \\
\hline & & Hepa & .50057 & .228 \\
\hline & & Muscle & .41461 & .200 \\
\hline & \multirow[t]{2}{*}{ Gills } & Hepa & .10525 & .942 \\
\hline & & Muscle & .01930 & 1.000 \\
\hline & Hepa & Muscle & -.08595 & .925 \\
\hline \multirow[t]{7}{*}{${ }^{65} \mathrm{Cu}$} & \multirow[t]{3}{*}{ Exo } & Gills & -.03568 & 1.000 \\
\hline & & Hepa & .49148 & .168 \\
\hline & & Muscle & .36498 & .328 \\
\hline & \multirow[t]{2}{*}{ Gills } & Нера & .52716 & .320 \\
\hline & & Muscle & .40066 & .518 \\
\hline & Нера & Muscle & -.12650 & .999 \\
\hline & Tissue & Mean rank & Sum of rank & Sig. \\
\hline \multicolumn{5}{|c|}{ (b) (Mann-Whitney U) } \\
\hline \multirow[t]{12}{*}{${ }^{52} \mathrm{Cr}$} & Exo & 12.52 & 288 & .000 \\
\hline & Gills & 34.48 & 793 & \\
\hline & Exo & 28.17 & 648 & .018 \\
\hline & Hepa. & 18.83 & 433 & \\
\hline & Exo & 32.33 & 743.50 & .000 \\
\hline & Muscle & 14.67 & 337.50 & \\
\hline & Gills & 34.43 & 792 & .000 \\
\hline & Нера. & 12.57 & 289 & \\
\hline & Gills & 35.00 & 805 & .000 \\
\hline & Muscle & 12.00 & 276 & \\
\hline & Нера. & 25.91 & 596 & .223 \\
\hline & Muscle & 21.09 & 485 & \\
\hline \multirow[t]{2}{*}{${ }^{53} \mathrm{Cr}$} & Exo & 12.04 & 277 & .000 \\
\hline & Gills & 34.96 & 804 & \\
\hline
\end{tabular}

Table 2 continued

\begin{tabular}{|c|c|c|c|c|}
\hline & Tissue & Mean rank & Sum of rank & Sig. \\
\hline & Exo & 16.43 & 378 & .000 \\
\hline & Hepa. & 30.57 & 703 & \\
\hline & Exo & 20.43 & 470 & .121 \\
\hline & Muscle & 26.57 & 611 & \\
\hline & Gills & 34.22 & 787 & .000 \\
\hline & Нера. & 12.78 & 294 & \\
\hline & Gills & 35.00 & 805 & .000 \\
\hline & Muscle & 12.00 & 276 & \\
\hline & Hepa. & 30.91 & 711 & .000 \\
\hline & Muscle & 16.09 & 370 & \\
\hline \multirow[t]{12}{*}{ As } & Exo. & 24.26 & 558 & .701 \\
\hline & Gills & 22.74 & 523 & \\
\hline & Exo. & 25.43 & 585 & .328 \\
\hline & Hepa. & 21.57 & 496 & \\
\hline & Exo. & 35.00 & 805 & .000 \\
\hline & Muscle & 12.00 & 276 & \\
\hline & Gills & 24.72 & 568.50 & .538 \\
\hline & Hepa. & 22.28 & 512.50 & \\
\hline & Gills & 34.24 & 787.50 & .000 \\
\hline & Muscle & 12.76 & 293.50 & \\
\hline & Нера. & 35.00 & 805.00 & .000 \\
\hline & Muscle & 12.00 & 276.00 & \\
\hline
\end{tabular}

* The mean difference is significant at the 0.05 level $(p<0.05)$

Hepa.: Hepatopancreas, Exo.: Exoskeleton, Muscle: Abdominal muscle

${ }^{53} \mathrm{Cr}$ was accumulated in the following order: gills $>$ hepatopancreas $>$ exoskeleton $\approx$ abdominal muscle.

Mn yielded one of the highest accumulation rates in every tissue, likely because of its status as an essential element (Baden and Eriksson 2006). However, previous studies indicate that $\mathrm{Mn}$ accumulation in high concentrations may also have toxic effects (Baden and Eriksson 2006; Becquer et al. 2010). No significant difference was observed between the $\mathrm{Mn}$ accumulations in the hepatopancreas-exoskeleton and gills-muscle of male specimens. Other tissues had statistically significant differences. In the female cohort, differences between the Mn accumulation rates of abdominal muscle and both hepatopancreas and the exoskeleton were not significant. Mn accumulation was reported to be the most prevalent in gills or exoskeleton (Kurun et al. 2010; Naghshbandi et al. 2007). However, the greatest accumulation amounts were observed in the hepatopancreas for this study. In males, Mn was accumulated in the order: exoskeleton $\approx$ hepatopancreas $>$ gills $\approx$ abdominal muscle. In females, differences between tissue accumulation amounts were not pronounced enough to draw statistically significant conclusions, though hepatopancreas $\approx$ exoskeleton $>$ abdominal muscle $>$ gills was the general trend. 

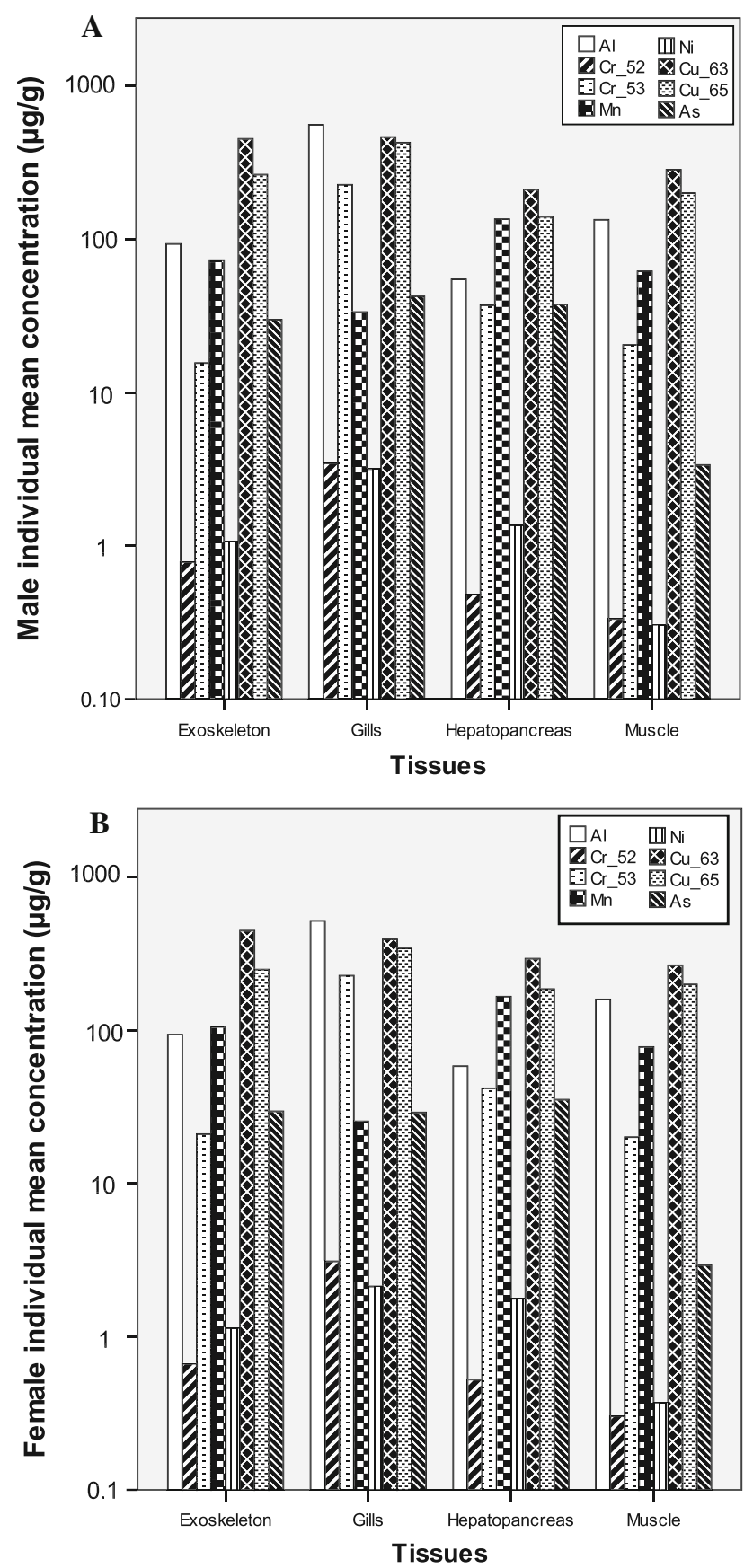

Fig. 1 a Metals and metalloid trends for male specimens. b Metals and metalloid trends for female specimens

It is still not well known whether $\mathrm{Ni}$ is essential for crayfish (Khan and Nugegoda 2003; Yilmaz and Yilmaz 2007). However, it constitutes a toxic environmental hazard at high concentrations, retarding growth and preventing reproductive activity (Khan and Nugegoda 2003). In male specimens, significant differences were observed in $\mathrm{Ni}$ accumulation for each tissue, except between the exoskeleton and hepatopancreas. In the female cohort, every tissue accumulated significantly more $\mathrm{Ni}$ than the abdominal muscle, but no other statistically significant difference was observed. Previous studies support our observations on $\mathrm{Ni}$ accumulation preferences by tissue (Khan and Nugegoda 2003). In males, Ni accumulation followed the order: gills $>$ exoskeleton $\approx$ hepatopancreas $>$ abdominal muscle. In females, the general order of $\mathrm{Ni}$ accumulation was gills: exoskeleton $\approx$ hepatopancreas $\approx$ gills $>$ abdominal muscle, although the gillsabdominal muscle connection does not have statistical support.

${ }^{63} \mathrm{Cu}$ accumulation yielded no significant differences across the tissues of female specimens, while only the differences between the hepatopancreas and other tissues were significant for the male cohort. In males, the order of accumulation of ${ }^{63} \mathrm{Cu}$ was: gills $\approx$ exoskeleton $\approx$ abdominal muscle $>$ hepatopancreas. In females, no significant difference was observed between the ${ }^{63} \mathrm{Cu}$ accumulation levels of each tissue. For the male cohort, hepatopancreatic accumulation of ${ }^{65} \mathrm{Cu}$ was significantly lower compared to gills and the exoskeleton, while no statistically meaningful difference was observed between abdominal muscles and the hepatopancreas. In addition, gill tissue accumulated significantly more ${ }^{65} \mathrm{Cu}$ than the abdominal muscles. Tissue accumulations of this metal exhibited no significant differences in females. In males, ${ }^{65} \mathrm{Cu}$ accumulation levels did not display large enough differences to yield a complete, statistically significant accumulation order, but gills $>$ exoskeleton $>$ abdominal muscle $>$ hepatopancreas was the generally observed result. In females, no significant difference was observed between the ${ }^{65} \mathrm{Cu}$ accumulation levels in any tissue. Differences in copper absorption between the genders are notable, as copper is a component of the carrier protein hemocyanin and therefore constitutes an essential element for crustaceans. The differences in copper accumulation between male and female specimens may be due to the time period at which the specimens were collected. As female specimens were ovigerous during the collection period, the eggs could have been supplied with copper from the female's tissues, thus explaining the depletion of copper in the latter and the lack of significant differences detected between tissues due to the low concentrations of copper. In the male cohort, copper accumulated primarily in the gills and the exoskeleton. Similar results indicating the gills as prime sites of copper absorption exist in the literature (Kurun et al. 2010), although the hepatopancreas was also reported as a site of absorption (Alcorlo et al. 2006; Naghshbandi et al. 2007). Also for female cohorts, accumulation rates between ${ }^{63} \mathrm{Cu}$ and ${ }^{65} \mathrm{Cu}$ were not significantly different in gills, hepatopancreas and muscle tissue, while for male cohorts significant differences were only lacking in gill tissue.

The toxicity of As depends primarily on the element's valance state, with inorganic $\mathrm{As}\left(\mathrm{As}^{3+}\right.$ and $\left.\mathrm{As}^{5+}\right)$ displaying the greatest toxicity (Batista et al. 2011; Li et al. 2011). Our 
Fig. 2 a Dendrogram of Cluster Analysis $(C A)$ for male specimens. b Dendrogram of Cluster Analysis $(C A)$ for female specimens

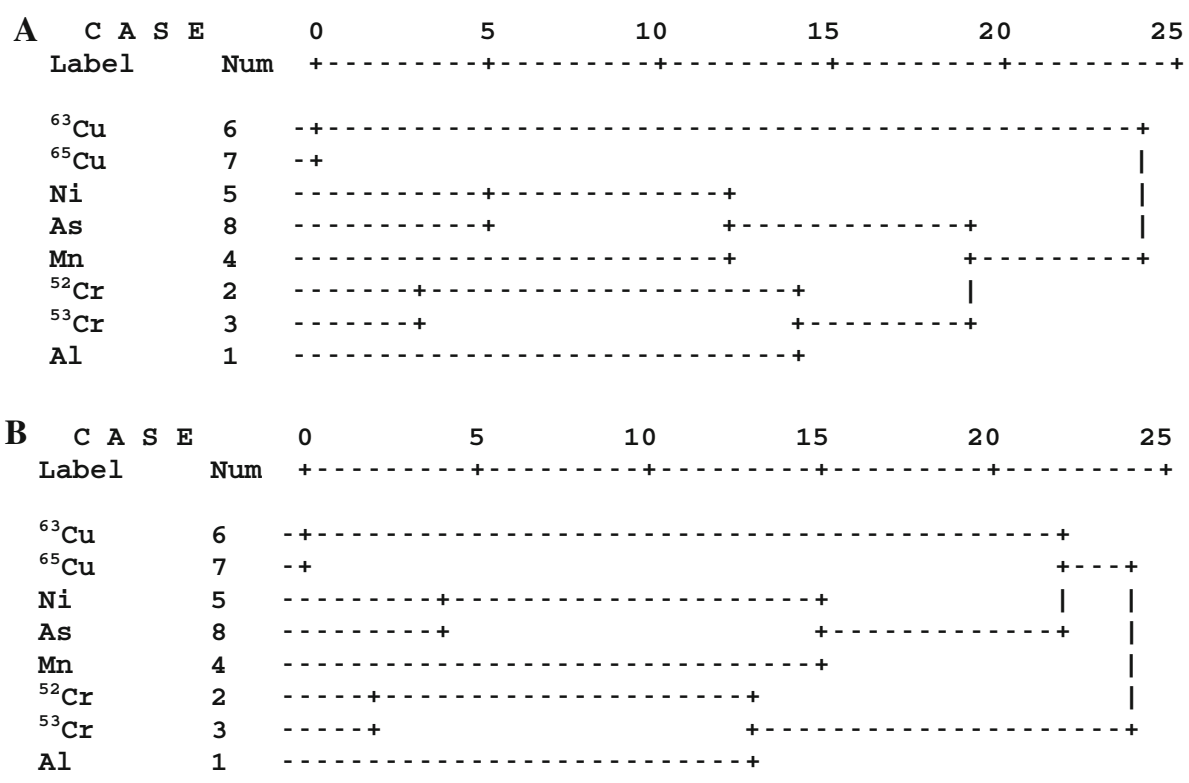

uptake of gills (Bondgaard et al. 2000). Females may have mechanisms of detoxification not present in males, such as toxins associated with circulating haemolymph lipoproteins that are incorporated into developing oocytes (Lee 1993). This suggests that the transfer of heavy metals into oocytes may relieve females of some of the effects of toxic metals (Martín-Díaz et al. 2006). This conclusion is supported by a strong correlation we have previously observed between $\mathrm{Ni}$ and As accumulations in female specimens, especially in gill tissue $\left(\mathrm{R}^{2}=0.826\right)$ (Tunca et al. 2013).

Cluster analysis yielded three closely related clusters, with $\mathrm{Al}$ and $\mathrm{Mn}$ relatively distant from the more closely related pairs (Fig. 2a, b). Despite slight differences in their sorption trends, ${ }^{63} \mathrm{Cu}$ and ${ }^{65} \mathrm{Cu}$ were recovered in a very close cluster $\left(\left({ }^{63} \mathrm{Cu},{ }^{65} \mathrm{Cu}\right)=4.626\right.$ for males, 4.008 for females). ${ }^{52} \mathrm{Cr}$ and ${ }^{53} \mathrm{Cr}$ likewise formed a single cluster with relatively low Euclidean distances between the isotopes $\left(\left({ }^{52} \mathrm{Cr},{ }^{53} \mathrm{Cr}\right)=6.918\right.$ for males, 5.267 for females $)$. $\mathrm{Ni}$ and As were recovered together, possibly because crayfish utilize the same methods to detoxify those elements $((\mathrm{Ni}, \mathrm{As})=8.517$ for males, 6.379 for females $)$. It is notable that $\mathrm{Ni}$ and As both displayed a lack of accumulation in female crayfish tissues compared to males. It is apparent that $\mathrm{Al}$ has the most unusual accumulation profile among the studied metals, as Al constitutes a cluster by itself and this cluster bears great distances to other metals for both genders (e.g. ( $\left.\mathrm{Al},{ }^{52} \mathrm{Cr}\right)=12.910$ for males, 10.014 for females). This may be because of the low toxicity of $\mathrm{Al}$ or its status as a trivalent cation. The latter explanation would also account for the presence of $\mathrm{Cr}$ as the element clustered closest to $\mathrm{Al}$, since $\mathrm{Cr}$ is generally trivalent in organic systems.

Regression analysis was also applied to the elements in all tissues to determine accumulation models. Models with maturation in Carcinus maenas resulted in diminished $\mathrm{Cd}$ 
Table 3 Regression models for males and females

\begin{tabular}{|c|c|}
\hline Regression models (Male) & $\mathrm{R}^{2}$ \\
\hline${ }^{52} C r_{\text {Hepa }}=0.01\left({ }^{53} C r_{\text {Hepa }}\right)+0.01\left({ }^{63} C u_{\text {Exo }}\right)-0.1$ & 0.921 \\
\hline${ }^{53} \mathrm{Cr}_{\text {Hepa }}=75.51\left({ }^{52} \mathrm{Cr}_{\text {Hepa }}\right)+3.27\left(N i_{\text {Gills }}\right)-0.65\left(A s_{\text {Exo }}\right)+2.336$ & 0.928 \\
\hline${ }^{52} C r_{\text {Gills }}=0.01\left({ }^{65} C u_{\text {Gills }}\right)+2.11\left(N i_{\text {Exo }}\right)+0.01\left({ }^{63} C u_{\text {Muscle }}\right)+0.001\left(M n_{\text {Muscle }}\right)-1.2$ & 0.875 \\
\hline${ }^{63} \mathrm{Cu}$ Gills $=1.474\left({ }^{65} \mathrm{C} u_{\text {Gills }}\right)-11.2\left(A s_{\text {Exo }}\right)+170.08$ & 0.916 \\
\hline${ }^{65} C u_{\text {Gills }}=0.51\left({ }^{63} C u_{\text {Gills }}\right)+6.99\left(A s_{\text {Exo }}\right)+42.08\left({ }^{52} C r_{\text {Gills }}\right)-128$ & 0.961 \\
\hline${ }^{63} \mathrm{C} u_{\text {Hepa }}=1.79\left({ }^{65} \mathrm{C} u_{\text {Hepa }}\right)-0.13\left({ }^{65} \mathrm{C} u_{\text {Gills }}\right)-15.05$ & 0.864 \\
\hline${ }^{65} \mathrm{Cu}$ Hера $=0.45\left({ }^{63} \mathrm{Cu}\right.$ Hера $)+44.19\left({ }^{52} \mathrm{Cr}_{\text {Exo }}\right)+11.13$ & 0.882 \\
\hline${ }^{63} \mathrm{C} u_{\text {Muscle }}=0.86\left({ }^{65} C u_{\text {Muscle }}\right)+1.33\left(A s_{\text {Hepa }}\right)+61.01$ & 0.921 \\
\hline${ }^{65} \mathrm{Cu}$ Muscle $=0.96\left({ }^{63} \mathrm{C} u_{\text {Muscle }}\right)+110.14\left(N i_{\text {Muscle }}\right)-31.54\left({ }^{52} C r_{E x o}\right)-81.15$ & 0.936 \\
\hline${ }^{63} C u_{E x o}=1.483\left({ }^{65} C u_{E x o}\right)-0.126\left({ }^{63} C u_{G i l l s}\right)+7.3\left(A s_{E x o}\right)-99.1$ & 0.891 \\
\hline${ }^{65} C u_{E x o}=0.456\left({ }^{63} C u_{E x o}\right)+0.066\left({ }^{63} C u_{\text {Gills }}\right)-3.685$ & 0.893 \\
\hline$M n_{\text {Muscle }}=252.4\left(N i_{\text {Muscle }}\right)-15.23$ & 0.851 \\
\hline$N i_{\text {Muscle }}=0.01\left(M n_{\text {Muscle }}\right)-0.02\left(N i_{\text {Gills }}\right)+0.2$ & 0.882 \\
\hline$N i_{\text {Gills }}=0.36\left(\right.$ As $\left.\left._{\text {Hepa }}\right)+0.96\left(N i_{\text {Exo }}\right)-0.01{ }^{65} C u_{\text {Muscle }}\right)+0.01\left({ }^{65} C u_{\text {Hepa }}\right)+0.01\left({ }^{63} C u_{\text {Gills }}\right)+0.35$ & 0.857 \\
\hline$A s_{\text {Exo }}=0.2\left(A s_{\text {Hepa }}\right)+10.28\left({ }^{52} C r_{\text {exo }}\right)-0.12\left({ }^{53} C_{\text {Hepa }}\right)-11.64\left(N i_{\text {Muscle }}\right)+22.22$ & 0.874 \\
\hline Regression models (Female) & $\mathrm{R}^{2}$ \\
\hline${ }^{52} C r_{\text {Hepa }}=0.01\left({ }^{53} C r_{\text {Hepa }}\right)+0.01\left({ }^{65} C u_{\text {Exo }}\right)-0.13$ & 0.930 \\
\hline${ }^{53} \mathrm{Cr}_{\text {Hepa }}=79.58\left({ }^{52} \mathrm{C} r_{\text {Hepa }}\right)-0.06\left({ }^{65} \mathrm{C} u_{\text {Exo }}\right)+0.02\left({ }^{63} \mathrm{C} u_{\text {Hepa }}\right)+7.11$ & 0.935 \\
\hline${ }^{63} C u_{E x o}=1.96\left({ }^{65} C u_{E x o}\right)+0.43\left({ }^{63} C u_{\text {Muscle }}\right)-157.61$ & 0.968 \\
\hline${ }^{65} C u_{E x o}=0.41\left({ }^{63} C u_{E x o}\right)-0.38\left(M n_{M u s c l e}\right)+94.59$ & 0.965 \\
\hline${ }^{63} \mathrm{C} u_{\text {Gills }}=1.25\left({ }^{65} \mathrm{C} u_{\text {Gills }}\right)+2.05\left({ }^{53} C r_{\text {Hepa }}\right)-121.43$ & 0.886 \\
\hline${ }^{65} \mathrm{C} u_{\text {Gills }}=0.52\left({ }^{63} \mathrm{C} u_{\text {Gills }}\right)+0.65\left({ }^{65} C u_{\text {Exo }}\right)-23.6$ & 0.899 \\
\hline${ }^{63} \mathrm{C} u_{\text {Hepa }}=0.88\left({ }^{65} \mathrm{C} u_{\text {Hepa }}\right)-0.18\left({ }^{63} C u_{\text {Gills }}\right)+3.41\left({ }^{53} C r_{\text {Hepa }}\right)+0.47\left({ }^{65} C u_{\text {Muscle }}\right)-38.36$ & 0.912 \\
\hline${ }^{63} C u_{\text {Muscle }}=0.82\left({ }^{65} C u_{\text {Muscle }}\right)+0.08\left({ }^{65} C u_{\text {Gills }}\right)-0.44\left({ }^{53} C r_{\text {Hepa }}\right)+91.12$ & 0.970 \\
\hline${ }^{65} \mathrm{C} u_{\text {Muscle }}=1.08\left({ }^{63} \mathrm{C} u_{\text {Muscle }}\right)-0.07\left({ }^{65} \mathrm{C} u_{\text {Gills }}\right)+0.07\left({ }^{63} \mathrm{C} u_{\text {Hepa }}\right)-85.88$ & 0.969 \\
\hline
\end{tabular}

$R^{2}$ Coefficients of determination

coefficients of determination $\left(\mathrm{R}^{2}\right)>0.85$ were included (Tables 3a, b). Concentrations of $\mathrm{Cu}$ and $\mathrm{Cr}$ isotopes could be predicted in many cases, possibly because each individual isotope formed a basis for prediction of the other. Close clustering of isotopes, observed for both $\mathrm{Cu}$ and $\mathrm{Cr}$, also reflect a similar behaviour.

In conclusion, differences in the accumulation and distribution of heavy metals ( $\mathrm{Al}, \mathrm{Cr}\left(\mathrm{Cr}^{52}, \mathrm{Cr}^{53}\right), \mathrm{Cu}\left(\mathrm{Cu}^{63}\right.$, $\left.\mathrm{Cu}^{65}\right), \mathrm{Mn}, \mathrm{Ni}$ ) and a metalloid (As) were characterized separately in four tissues (exoskeleton, gills, hepatopancreas and abdominal muscle tissue) of male and female crayfish, and the data were used to develop prediction models for the bioaccumulation of these elements in crayfish. The four tissue types tested yielded significantly different accumulation trends for every element tested, except $\mathrm{Al}$, between male and female cohorts. Further, accumulation rates of $\mathrm{Ni}$ and $\mathrm{As}$ were noted to be different in gill tissues of male and female cohorts. The accumulations of these heavy metals were significantly less in female gill tissue compared to the gill tissue in males. Likewise, gender was observed to significantly affect the accumulation profile of $\mathrm{Cu}$ isotopes. For female cohorts, accumulation rates between ${ }^{63} \mathrm{Cu}$ and ${ }^{65} \mathrm{Cu}$ were not significantly different in gills, hepatopancreas and muscle tissue while for male cohorts, significant differences were observed in all tissues tested, except the gills. Furthermore, this study determined the effect of each element on the accumulation of other elements, with accumulation models presented for those relationships with $\mathrm{R}^{2}>0.85$. This information may be of value to future laboratory and field investigations.

Acknowledgments We thank Erdem Akıncı for his expert guidance in carrying out the ICP-MS measurements. This work is supported by the Turkish National Nanotechnology Research Center (UNAM) and Grants by the State Planning Organization of Turkey (DPT). 


\section{References}

Agrawal J, Sherameti I, Varma A (2011) Detoxification of heavy metals: state of art. Springer-Verlag, Berlin

Alcorlo P, Otero M, Crehuet M, Baltanás A, Montes C (2006) The use of the red swamp crayfish (Procambarus clarkii, Girard) as indicator of the bioavailability of heavy metals in environmental monitoring in the River Guadiamar (SW, Spain). Sci Total Environ 366(1):380-390

Alexopoulos E, McCrohan CR, Powell JJ, Jugdaohsingh R, White KN (2003) Bioavailability and toxicity of freshly neutralized aluminium to the freshwater crayfish Pacifastacus leniusculus. Arch Environ Contam Toxicol 45(4):509-514

Anderson MB, Reddy P, Preslan JE, Fingerman M, Bollinger J, Jolibois L, Maheshwarudu G, George WJ (1997a) Metal accumulation in crayfish, Procambarus clarkii, exposed to a petroleum-contaminated bayou in Louisiana. Ecotoxicol Environ Saf 37:267-272

Anderson MB, Preslan JE, Jolibois L, Bollinger JE, George WJ (1997b) Bioaccumulation of lead nitrate in red swamp crayfish (Procambarus clarkii). J Hazard Mater 54(1-2):15-29

Baden SP, Eriksson SP (2006). Role, routes and effects of manganese in crustaceans. In R. N. Gibson, R. J. A. Atkinson, J. D. M. Gordon (eds.), Oceanogr Mar Biol 44, 61-83

Barrento S, Marques A, Teixeira B, Vaz-Pires P, Carvalho ML, Nunes ML (2008) Essential elements and contaminants in edible tissues of European and American lobsters. Food Chem 111(4): $862-867$

Batista BL, Souza JMO, De Souza SS, Barbosa F (2011) Speciation of arsenic in rice and estimation of daily intake of different arsenic species by Brazilians through rice consumption. J Hazard Mater 191(1-3):342-348

Becquer T, Quantin C, Boudot J (2010) Toxic levels of metals in Ferralsols under natural vegetation and crops in New Caledonia. Eur J Soil Sci 61(6):994-1004

Bernhard M (1976). Manual of methods in aquatic environment research, part. 3: sampling and analyses of biological material. FAO Fish Tech Paper No. 158, UNEP Rome

Bollinger JE, Bundy K, Anderson MB, Millet L, Preslan JE, Jolibois L, Hsiao-Lin C, Kamath B, George WJ (1997) Bioaccumulation of chromium in red swamp crayfish (Procambarus clarkii). J Hazard Mater 54:1-13

Bondgaard M, Norum U, Bjerregaard P (2000) Cadmium accumulation in the female shore crab Carcinus maenas during the moult cycle and ovarian maturation. Mar Biol 137(5-6):9951004

Guner U (2007) Freshwater crayfish Astacus leptodactylus (Eschscholtz, 1823) accumulates and depurates copper. Environ Monit Assess 133(1-3):365-369

Hagen JP, Sneddon J (2009) Determination of copper, iron, and zinc in crayfish (Procambarus clarkii) by inductively coupled plasmaoptical emission spectrometry. Spectrosc Lett 42(1):58-61

Hothem RL, Bergen DR, Bauer ML, Crayon JJ, Meckstroth AM (2007) Mercury and trace elements in crayfish from Northern California. Bull Environ Contam Toxicol 79(6):628-632
Khan S, Nugegoda D (2003) Australian freshwater crayfish Cherax destructor accumulates and depurates nickel. Bull Environ Contam Toxicol 70(2):308-314

Kouba A, Buřič M, Kozák P (2010) Bioaccumulation and effects of heavy metals in crayfish: a review. Water Air Soil Pollut 211(1-4):5-16

Kurun A, Balkıs N, Erkan M, Balkıs H, Aksu A, Erşan MS (2010) Total metal levels in crayfish Astacus leptodactylus (Eschscholtz, 1823), and surface sediments in Lake Terkos Turkey. Environ Monit Assess 169(1-4):385-395

Lee RF (1993) Passage of xenobiotics and their metabolites from hepatopancreas into ovary and oocytes of blue crabs, Callinectes-sapidus-possible implications for vitellogenesis. Mar Environ Res 35(1-2):181-187

Li G, Sun GX, Williams PN, Nunes L, Zhu YG (2011) Inorganic arsenic in Chinese food and its cancer risk. Environ Int 37(7): 1219-1225

Lopez FJS, Garcia MDG, Vidal JLM, Aguilera PA, GarridoFrenich A (2004) Assessment of metal contamination in Doñana National Park (Spain) using crayfish (Procamburus clarkii). Environ Monit Assess 93:17-29

Martín-Díaz ML, Tuberty SR, McKenney CL, Blasco J, Sarasquete C, DelValls TA (2006) The use of bioaccumulation, biomarkers and histopathology diseases in Procambarus clarkii to establish bioavailability of $\mathrm{Cd}$ and $\mathrm{Zn}$ after a mining spill. Environ Monit Assess 116(1-3):169-184

Naghshbandi N, Zare S, Heidari R, Razzaghzadeh S (2007) Concentration of heavy metal in different tissues of Astacus leptodactylus from Aras Dam of Iran. Pak J Biol Sci 10(21):3956-3959

Pick D, Leiterer M, Einax JW (2010) Reduction of polyatomic interferences in biological material using dynamic reaction cell ICP-MS. Microchem J 95(2):315-319

Soedarini B, Klaver L, Roessink I, Widianarko B, van Straalen NM, van Gestel CAM (2012) Copper kinetics and internal distribution in the marbled crayfish (Procambarus sp.). Chemosphere 87(4):333-338

Srinath T, Verma T, Ramteke PW, Garg SK (2002) Chromium (VI) biosorption and bioaccumulation by chromate resistant bacteria. Chemosphere 48(4):427-435

Suárez-Serrano A, Alcaraz C, Ibáñez C, Trobajo R, Barata C (2010) Procambarus clarkii as a bioindicator of heavy metal pollution sources in the lower Ebro River and Delta. Ecotoxicol Environ Saf 73(3):280-286

Tunca E, Ucuncu E, Ozkan AD, Ulger ZE, Tekinay T (2013) Tissue Distribution and Correlation Profiles of Heavy-Metal Accumulation in the Freshwater Crayfish Astacus leptodactylus. Arch Environ Contam Toxicol. doi:10.1007/s00244-012-9863-3

Vinod VTP, Sashidhar RB, Sreedhar B (2010) Biosorption of nickel and total chromium from aqueous solution by gum kondagogu (Cochlospermum gossypium): a carbohydrate biopolymer. J Hazard Mater 178(1-3):851-860

Wigginton AJ, Birge WJ (2007) Toxicity of cadmium to six species in two genera of crayfish and the effect of cadmium on molting success. Environ Toxicol Chem 26(3):548-554

Yilmaz A, Yilmaz L (2007) Influences of sex and seasons on levels of heavy metals in tissues of green tiger shrimp (Penaeus semisulcatus de Hann, 1844). Food Chem 101(4):1664-1669 